\title{
Alternative control to black spot disease in papaya genotypes
}

\author{
Pedro Henrique Dias dos Santos ${ }^{1}$; Silvaldo Felipe da Silveira ${ }^{1}$; Marcelo Vivas ${ }^{2}$; Beatriz Murizini Carvalho ${ }^{1}$; Messias \\ Gonzaga Pereira ${ }^{2}$
}

\begin{abstract}
${ }^{1}$ Laboratório de Entomologia e Fitopatologia; ${ }^{2}$ Laboratório de Genética e Melhoramento de Plantas. Universidade Estadual do Norte Fluminense Darcy Ribeiro. Av. Alberto Lamego, 2000 CEP 28013-602, Campos dos Goytacazes, RJ Brasil.

Corresponding author: Pedro Henrique Dias dos Santos (pedroh_dias@hotmail.com)

Data de chegada: 16/06/2016. Aceito para publicação em: 16/08/2016.
\end{abstract}

$10.1590 / 0100-5405 / 2208$

\section{ABSTRACT}

Santos, P.H.D.; Silveira, S.F.; Vivas, M.; Carvalho, B.M.; Pereira, M.G. Alternative control to black spot disease in papaya genotypes. Summa Phytopathologica, v.43, n.1, p.60-62, 2017.

To find control forms alternative to fungicides, this study aimed to evaluate the effect of products with potential to control black spot (Asperisporium caricae) in different papaya genotypes. Installed in a greenhouse, the experiment was conducted in randomized blocks (RB) with factorial arrangement $5 \times 6$, three replicates, and spraying of four products $\left(\mathrm{Bion}^{\circledR}\right.$, Bordeaux mixture, Ecolife ${ }^{\circledR}$, and Bordasul ${ }^{\circledR}$ ) in six papaya genotypes ('Sunrise Solo PT', 'STZ 03', 'Golden', 'Tailândia', 'Maradol' and 'UENF-CALIMAN $\left.01^{\prime}\right)$, while control was sprayed only with water. The severity (BSS) and the incidence (BSI) of black spot on the leaves were quantified, as well as the area under the disease progress curve (AUDPC). There was variability among the evaluated genotypes, highlighting 'STZ 03', 'Maradol' and 'UENF/ CALIMAN 01' as the most resistant genotypes. 'Tailândia' (susceptible) showed greater response to the products. Plants sprayed with Bion ${ }^{\circledR}$, Bordeaux mixture and Bordasul ${ }^{\circledR}$ had reduced black spot means.

Keywords: Carica papaya, Asperisporium caricae, genetic resistance

\section{RESUMO}

Santos, P.H.D.; Silveira, S.F.; Vivas, M.; Carvalho, B.M.; Pereira, M.G.Controle alternativo de pinta-preta em genótipos de mamoeiro. Summa Phytopathologica, v.43, n.1, p.60-62, 2017.

Visando encontrar formas de controle alternativas aos fungicidas, delineou-se este trabalho com objetivo de avaliar em diferentes genótipos de mamoeiro o efeito de produtos com potencial para o controle da pinta-preta (Asperisporium caricae). Instalou-se em telado, um experimento em DBC com arranjo em fatorial 5x6, com três repetições, onde foram pulverizados quatro produtos (Bion ${ }^{\circledR}$, Calda Bordalesa, Ecolife ${ }^{\circledR}$ e Bordasul ${ }^{\circledR}$ ) em seis genótipos de mamoeiro ('Sunrise Solo PT', 'STZ 03', 'Golden', 'Tailândia', 'Maradol'e 'UENF-CALIMAN 01'), na testemunha pulverizou-se apenas água. Quantificou-se a severidade (SPP) e incidência (IPP) de Pinta-Preta nas folhas, bem como a área abaixo da curva de progresso de doença (AACPD). Houve variabilidade entre os genótipos avaliados, destacando como os mais resistentes 'STZ 03'; 'Maradol' e 'UENF/ CALIMAN 01'. O genótipo 'Tailândia' (suscetível) apresentou maior resposta aos produtos. Plantas pulverizadas com Bion ${ }^{\circledR}$, Calda Bordalesa e Bordasul ${ }^{\circledR}$ apresentaram médias reduzidas de Pinta-Preta.

Palavras-chave: Carica papaya, Asperisporium caricae, Resistência genética

Papaya black spot (Asperisporium caricae (Speg.) Maubl.) occurs on leaves and fruits, depreciating their commercial value. To prevent the damage caused by this pathogen, farmers have adopted several control measures. Some recommended measures are the removal of leaves and fruits showing symptoms from the orchard to reduce the initial inoculum (7), and the application of protective or systemic fungicides when the first symptoms appear (7).

This crop is still dependent on fungicide application to ensure a profitable production, and although there are 30 commercial products registered to combat the disease in papaya (1), its control is not total yet. Allied to this is the increasing worldwide demand for less toxic inputs, reinforcing and justifying the search for alternatives to fungicides in the control of black spot. Among these alternatives stand out cultivation in a protected environment (5), biological control (9), use of alternative products (6) and study of genetic resistance with evaluation of genotypes $(3,8)$. However, there is not an alternative and effective method to control $A$. caricae; therefore, the use of fungicides is still a reality for the papaya crop and a challenge to be overcome.

As an alternative to fungicides, induced resistance has great potential for the use in plant disease control. This type of resistance has considerable effects against a wide range of pathogens, including viruses, bacteria and fungi, activated by biotic or abiotic inducers. Papaya plants sprayed with acibenzolarS-methyl (ASM) have shown reduced disease severity on the leaves by inducing partial resistance (6). These results show the possibility of using these products, particularly ASM, as an alternative to control papaya black spot; however, Oliveira \& Nishijima (6) evaluated the effect of ASM in one genotype and found that it is not possible to extrapolate results beyond the genetic material on which it was tested.

ASM has been used in other pathosystems, which shows the potential of this and other products to be used as an alternative to control black spot in papaya. For example, Furtado et al. (4) reported the use of Ecolife $^{\circledR}$ and ASM for banana anthracnose control in the post-harvest. The use of Bordeaux mixture has also been reported as an alternative for the disease control and is accepted by the organic agriculture.

We believed that the results obtained in a previous study on disease control using these products could be extended to black spot, resulting in a new possibility to control this disease in papaya as an alternative 
to fungicide spraying. For these reasons, we delineated this study to evaluate in different papaya genotypes the effect of alternative products with potential to control papaya black spot.

The experiment was conducted in a greenhouse, using the randomized complete block design with factorial arrangement of $5 \times 6$, three replicates, and experimental unit of one plant per pot, totaling 36 treatments. Six genotypes were tested ('Sunrise Solo PT', 'STZ 03', 'Golden', 'Tailândia', 'Maradol' and 'UENF/CALIMAN 01') with four alternative products: acibenzolar-S-methyl (Bion ${ }^{\circledR}$, Syngenta), $0.025 \mathrm{~g}$ a.i./L; foliar fertilizer (Ecolife ${ }^{\circledR}$, Quinabra), $1 \mathrm{~mL}$ c.p./L; foliar fertilizer based on copper $25 \%$ and calcium $10 \%$ (Bordasul $^{\circledR}$, RCN agro), $1 \mathrm{~g}$ c.p.//L; and Bordeaux mixture, containing $0.4 \mathrm{~g} / \mathrm{L}_{\text {of CuSO}}$ and $0.15 \mathrm{~g} / \mathrm{L}$ of hydrated lime. The products were diluted in $4 \mathrm{~L}$ of water at $\mathrm{pH}$ around 6.5 and biweekly sprayed with a backpack sprayer, totaling 5 sprayings. The control treatment was sprayed only with water.

Inoculation was natural since in the surrounding of the greenhouse there were several adult papaya plants with symptoms of the disease. Evaluations started at 2 months after planting. The incidence and the severity of black spot on the leaves were weekly evaluated (five evaluations). The incidence of black spot symptoms (BSI) on the leaves was obtained based on the ratio between the number of symptomatic leaves and the total number of leaves. Black spot severity (BSS) was estimated for the fifth leaf according to the diagrammatic scale adopted by Vivas et al. (8). In addition, we estimated the area under the disease progress curve (AUDPC) based on the disease severity assessed for a previously marked leaf(second fully expanded leaf without symptoms), as established by Campbell \& Madden (2).

AUDPC values and BSI and BSS mean values were used to conduct the analysis of variance, and when the effect of genotype $\mathrm{x}$ products was significant, ramifications of changing sources were carried out. The treatment means were compared according to Tukey's test at 5\% probability.

For BSS, there was a significant interaction effect, and data will be presented and discussed separately. On the other hand, for BSI and AUDPC, there was no effect of the genotype inducing interaction; thus, the analyses were conducted by using the joint analysis data.

As observed in the analysis of variance, for the test mean, there was also a significant effect of the genotype on the three studied variables (Figure 1; Table 1). For BSS, the genotype 'Tailândia' showed the highest levels, while the genotypes 'Maradol' and 'STZ 03' had the lowest levels (Table 1). 'Maradol' also had the lowest AUDPC and BSI means (Figure 1), confirming its potential as a source of resistance, as observed by Vivas et al. (8). In addition to 'Maradol', 'UENF/ CALIMAN 01' also had the lowest AUDPC and BSI means (Figure 1). On the other hand, the genotypes 'Golden' and 'Tailândia' presented the highest values of BSI and AUDPC (Figure 1). Dianese et al. (3) and Vivas et al. (8) highlighted 'Golden' as the genotype most susceptible to this disease. Dianese et al. (3) also observed higher BSS means for 'Sunrise Solo' and 'Tailândia'.

For BSS, we observed a significant effect of genotype $\mathrm{x}$ inducing interaction; in this sense, it is convenient to select the best products according to each genotype. For 'STZ 03', although the mean ranged from 0.23 (plants sprayed with water) to 0.01 (plants sprayed with Bion $\left.^{\circledR}\right)$, there was not a significant difference among the tested products. The same was observed for 'Sunrise Solo PT' and 'Maradol' genotypes (Table 1). Black spot severity for 'Golden and 'UENF/CALIMAN 01' sprayed with Bion ${ }^{\circledR}$ and Bordasul ${ }^{\circledR}$ showed a reduction by up to $45 \%$, compared to control, which indicates the potential of these products to control black spot. The genotype 'Tailândia', considered the most susceptible genotype in this study, when sprayed with Bordasul ${ }^{\circledR}$ and Bordeaux mixture, showed a reduction in the disease severity, evidencing that the interaction in the control may be associated with
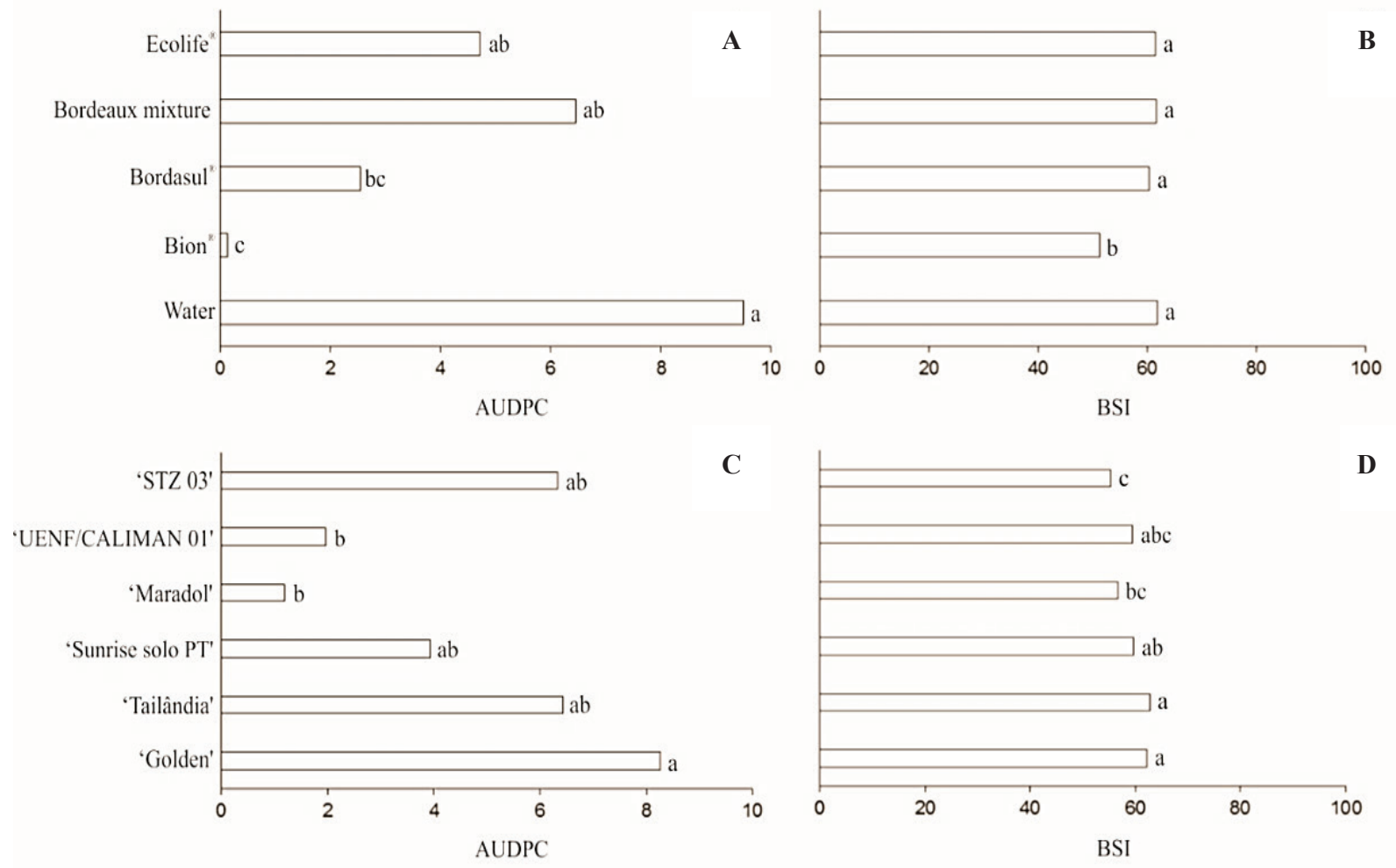

Figure 1. Means of area under the disease progress curve (AUDPC) and Black Spot (Asperisporium caricae) Incidence (BSI) in different papaya genotypes (C and D), and the effect of alternative products (A and B). 
Table 1. Means of Black Spot Severity (BSS) in different papaya genotypes biweekly sprayed with alternative products.

\begin{tabular}{|c|c|c|c|c|c|c|c|c|c|c|}
\hline \multirow{3}{*}{$\begin{array}{c}\text { GENOTYPE } \\
\text { 'Golden' }\end{array}$} & \multicolumn{10}{|c|}{ TREATMENT } \\
\hline & \multicolumn{2}{|c|}{ Control } & \multicolumn{2}{|c|}{ Bion $^{\circledR}$} & \multicolumn{2}{|c|}{ Bordasul $^{\circledR}$} & \multicolumn{2}{|c|}{ Bordeaux mixture } & \multicolumn{2}{|c|}{ Ecolife $^{\circledR}$} \\
\hline & 1.32 & $\mathrm{ABb}$ & 0.60 & $\mathrm{Bb}^{*}$ & 0.98 & $\mathrm{ABabc}$ & 1.55 & $\mathrm{Aab}$ & 1.29 & $\mathrm{ABab}$ \\
\hline 'Tailândia' & 2.82 & $\mathrm{Aa}$ & 1.92 & $\mathrm{ABa}$ & 1.22 & $\mathrm{Bab}$ & 1.25 & $\mathrm{Bb}$ & 1.94 & $\mathrm{ABa}$ \\
\hline 'Sunrise Solo PT' & 1.47 & $\mathrm{Ab}$ & 0.70 & $\mathrm{Ab}$ & 0.66 & Aabc & 1.34 & $\mathrm{Ab}$ & 1.35 & $\mathrm{Aab}$ \\
\hline 'Maradol' & 0.98 & & 0.41 & & 0.49 & & 0.64 & & 0.49 & \\
\hline 'Uenf/Caliman 01' & 1.77 & & 0.79 & $\mathrm{Ab}$ & 1.47 & & 2.49 & $\mathrm{Abc}$ & 2.08 & Abc \\
\hline & & $\mathrm{ABb}$ & & $\mathrm{Cb}$ & & $\mathrm{BCa}$ & & $\mathrm{Aa}$ & & $\mathrm{ABa}$ \\
\hline 'Stz 03 ' & 0.23 & Ac & 0.01 & $\mathrm{Ab}$ & 0.09 & Ac & 0.11 & $\mathrm{Ac}$ & 0.18 & $\mathrm{Ac}$ \\
\hline
\end{tabular}

* Means followed by the same lowercase letters in the column and the same capital letters on the line, for the same year, do not differ according to Tukey's test at 0.05 probability level.

the genotype and the product.

On the other hand, for AUDPC and BSI, there was no interaction between genotype and product, i.e., independent of the tested genotype, the product had the same effect. Thus, plants sprayed with Bion ${ }^{\circledR}$ had the lowest AUDPC means, followed by plants sprayed with Bordasul ${ }^{\circledR}$ (Figure 1), and both can be used to reduce the disease severity in papaya. Some studies have reported ASM as a potential inducer of resistance to black spot in papaya (6), but there are no reports of the potential of Bordasul $l^{\circledR}$ for this culture, which gives originality to the present study. However, treatment with Bordasul ${ }^{\mathbb{B}}, 1 \mathrm{~g}$ c.p./L, caused phytotoxicity in the plants. Reducing the dose of this product may reduce the phytotoxic effect on the leaves.

We did not observe phytotoxic effect in plants treated with Bion $^{\circledR}$. In addition, this product reduced the BSI mean on the leaves (Figure 1 ); this fact indicates that it is a resistance inducer product (6), which works in the plant as a whole, triggering pre-existing defense reactions and thus protecting it completely.

Our results suggest that, for the protection of the studied papaya genotypes, there was a synergistic effect of the genotype with the products tested for black spot control, especially for the most resistant genotypes sprayed with acibenzolar-S-methyl $\left(\mathrm{ASM} / \mathrm{Bion}^{\circledR}\right)$.

\section{REFERENCES}

1. Agrofit. Sistemas de Agrotóxicos Fitossanitários. Brasília, 2016. <http:// agrofit.agricultura.gov.br/agrofit_cons/principal_agrofit_cons $>$. Acesso em: 22 Maio 2016.

2. Campbell, C. L.; Madden, L.V. Introduction to plant disease epidemiology. Ed. New York: J. Wiley, 1990. 532p.

3. Dianese, A. C.,; Blum, L. E. B.,; Dutro, J. B., Lopes, L. F., Sena, M. C., Freitas, L. F., Yamanishi, O. K. Reação de genótipos de mamoeiro à varíola e à podridão-do-pé. Fitopatologia Brasileira, Brasília v.32, p. 419-423, 2007. < http://dx.doi.org/10.1590/S0100-41582007000500008>

4. Furtado, L. M.; Rodrigues, A. A. C.; Araújo, V. S.; Silva, L. L. S.; Catarino, A. M. Utilização de Ecolife ${ }^{\circledR}$ e Acibenzolar-S-metil (ASM) no controle da antracnose da banana em pós-colheita. Summa Phytopathologica, Botucatu, v.36, n.3, p.237-239, 2010.

5. Martelleto, LAP; Ribeiro, RLD; Carmo, MGF; Sudo-Martelleto, M; Goes, A. Incidência da varíola, causada por Asperisporium caricae, em folhas de mamoeiros submetidos ao manejo orgânico, em diferentes ambientes de cultivo. Summa Phytopathologica, Botucatu, v.35, p.288-292, 2009. $<$ http://dx.doi.org/10.1590/S0100-54052009000400006>

6. Oliveira, A.; Nishijima, W. Induction of Resistance to Papaya Black Spot Elicited by Acibenzolar-S-Methyl. Plant Pathology Journal, Gangnamgu, v.13, n.2, p.120-124, 2014.

7. Suzuki M.S.; Zambolim L.; Liberato J.R. Progresso de doenças fúngicas e correlação com variáveis climáticas em mamoeiro. Summa Phytopathologica, Botucatu, v.33, p.167-177, 2007. Disponível em: <http://www.scielo. br/pdf/sp/v33n2/a11v33n2.pdf>. Acesso em: 22 Maio 2016.

8. Vivas, M.; Silveira, S. F.; Vivas, J. M. S.; Pereira, M. G. Patometria, parâmetros genéticos e reação de progênies de mamoeiro à pinta-preta. Bragantia, Campinas, v. 71, p. 235-238, 2012. Disponível em: $<$ http://www.scielo.br/pdf/brag/2012nahead/aop_1409_12.pdf> Acesso em: 05 Maio 2016.

9. Vivas, J. M. S.; Vivas, M.; Silveira, S. F. Efeito da temperatura sobre o crescimento e esporulação in vitro de fungos hiperparasitas de Asperisporium caricae. Pesquisa Agropecuária Tropical, Goiânia, v.45, n.1, p.73-81, 2015. 